\title{
DIFFERENT POLYMORPHIC MODIFICATIONS OF PHENYL SALICYLATE
}

\author{
N.A. DAVYDOVA, V.I. MELNIK, V.V. NESPRAVA, V.YA. REZNICHENKO
}

PACS 78.55.Kz, 61.50.Ks,

For the first time, the luminescence spectra of two polymorphic forms of phenyl salicylate (salol) have been obtained. Both spectra show the vibronic structure. The average spacing between vibronic components is $1250 \mathrm{~cm}^{-1}$. Based on the infrared spectroscopy study, it is concluded that the interval between vibronic components in the luminescence spectra corresponds to the $\nu(\mathrm{C}-\mathrm{OH})$ stretching vibration. The luminescence spectrum of the metastable phase is shifted by $760 \mathrm{~cm}^{-1}$ to the low-frequency side and is much wider relative to that in the stable phase. The presence of an $\mathrm{OH}$ group in the orto-position on the substituted ring results in the asymmetry of a molecule and the localization of an electronic excitation on this ring.

\section{Introduction}

Salol, phenyl salicylate, and phenyl-2-hydroxybenzoate $\left(\mathrm{HO}-\mathrm{C}_{6} \mathrm{H}_{4} \mathrm{COOC}_{6} \mathrm{H}_{5}\right)$ are three names for an ester with diversified applications, namely as a stabilizer for cellulosic and vinyl plastics and as an ingredient for suntan preparations. The hydroxyl group reacts with acetic acid to form acetylsalicylic acid (called aspirin), which is the most widely common antiseptic and antipyretic agent. Salol is formed with phenol which has antiseptic property as well [1].

Our previous study of salol was devoted to the determination of a role of the nucleation in the vitrification of supercooled liquids [2]. Salol was chosen because of its model glass-forming status, the existence of polymorphism, and the wealth of experimental studies with various spectroscopic techniques, such as Brillouin [3, 4], Raman scattering [5-8], optical Kerr effect spectroscopy [9-11], and dielectric spectroscopy [12, 13]. However, to

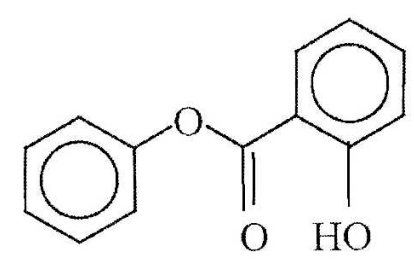

Fig. 1. Chemical structure of salol our knowledge, no work on the luminescence study of salol has been performed. This provides a stimulus to the detailed luminescence study, which can give interesting information on the different crystal polymorphs of salol. In addition, the Fourier-transform IR spectroscopy investigation of different modifications of salol has been performed as an aid for assigning the vibronic structure present in the emission.

\section{Experimental}

Salol of $99 \%$ purity was purchased from Aldrich and used without further purification. The chemical structure of salol is shown in Fig. 1. The molecule is an asymmetric one consisting of two phenyl rings, which are connected by three single bonds through two, carbon and oxygen, atoms. One hydroxyl group is attached on one of the phenyl rings in the orto-position and is involved in the formation of an intermolecular hydrogen bonding. Two crystalline modifications are known for salol: metastable (monoclinic) and stable (orthorhombic), with respective melting points of 302 and $315 \mathrm{~K}$ [14, 15]. The unit cell of metastable salol is approximately half that of the stable phase and contains four molecules, as opposed to the eight found in the stable modification.

For luminescence measurements, a dry powder was encapsulated in cylindrical glass tubes with the outer and inner diameters of 3 and $2 \mathrm{~mm}$, respectively, at room temperature and then melted using a heat gun. The glass phase of salol was obtained by the abrupt cooling of the liquid phase below the glass transition temperature region $\left(T_{g}=242 \mathrm{~K}\right)$. The metastable phase of salol was formed by the slow heating from the glass transition temperature to room temperature.

Luminescence spectra were recorded within a wide temperature range from 5.5 to $240 \mathrm{~K}$ using a MPF-4 Hitachi spectrofluorimeter in the spectral range 260-550 nm. The excitation from a xenon source was used. The spectra were recorded using the $250-\mathrm{nm}$ line as an excitation filtered by a monochromator. The width of the spectral slit is $2 \mathrm{~cm}^{-1}$. The emission from the crys- 


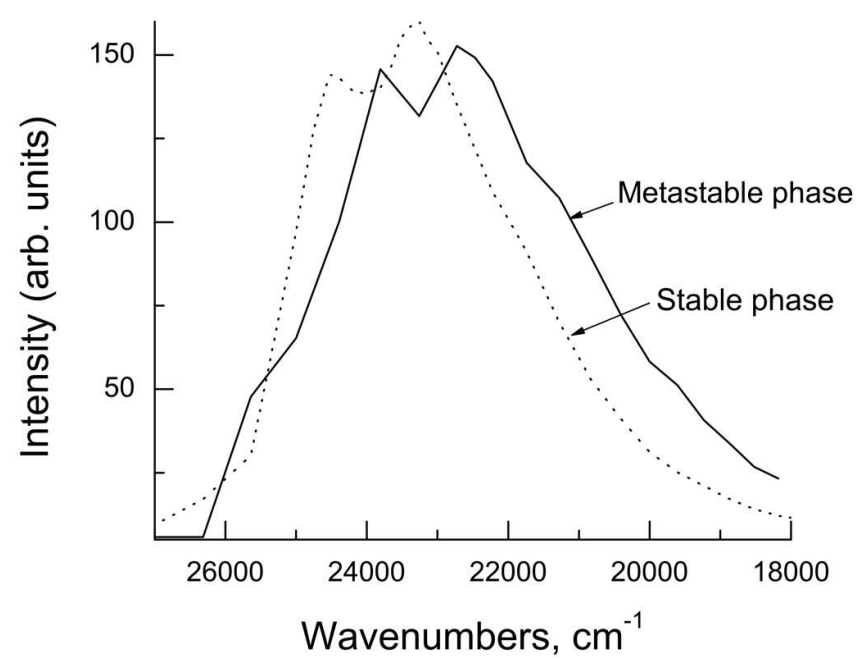

Fig. 2. Luminescence spectra of the stable (dotted curve) and metastable (solid curve) modifications of salol at $5.5 \mathrm{~K}$

tal was recorded with a FEU-79 photomultiplier in the photon-counting regime.

Infrared measurements were done at different temperatures on a Fourier-transform infrared spectrometer (Bruker model IFS-88) equipped with appropriate beam splitters to cover continuously the range $400-4000 \mathrm{~cm}^{-1}$. The resolution was $2 \mathrm{~cm}^{-1}$, and 32 scans were typically co-added for an individual spectrum. The data processing was performed with the OPUS software. For the IR transmittance measurements, the powder samples were inserted in a cell with two CsI pellets at room temperature and then melted into a thin film. The thickness of such a cell was approximately a few micrometers. Such sample with a liquid salol was then suited for an Oxford closed-cycle cryostat, which allows working temperatures down to $12 \mathrm{~K}$.

In the IR experiments, the liquid sample was quenched from room temperature below the glass transition temperature. The metastable phase was then prepared by heating from the glassy state and keeping isothermally the sample temperature at $260 \mathrm{~K}$. The stable phase was prepared by adding a crystalline powder to the edge of the cell with liquid salol to provide the crystallization.

\section{Results and Discussion}

In Fig. 2, we compare the luminescence spectra of the stable (dotted curve) and metastable (solid curve) polymorphic phases of salol at $5.5 \mathrm{~K}$ to clarify the difference between these two phases. At first glance, the both spectra appear fairly similar. They are asymmetric and broad and show the vibronic structure. However, sev-
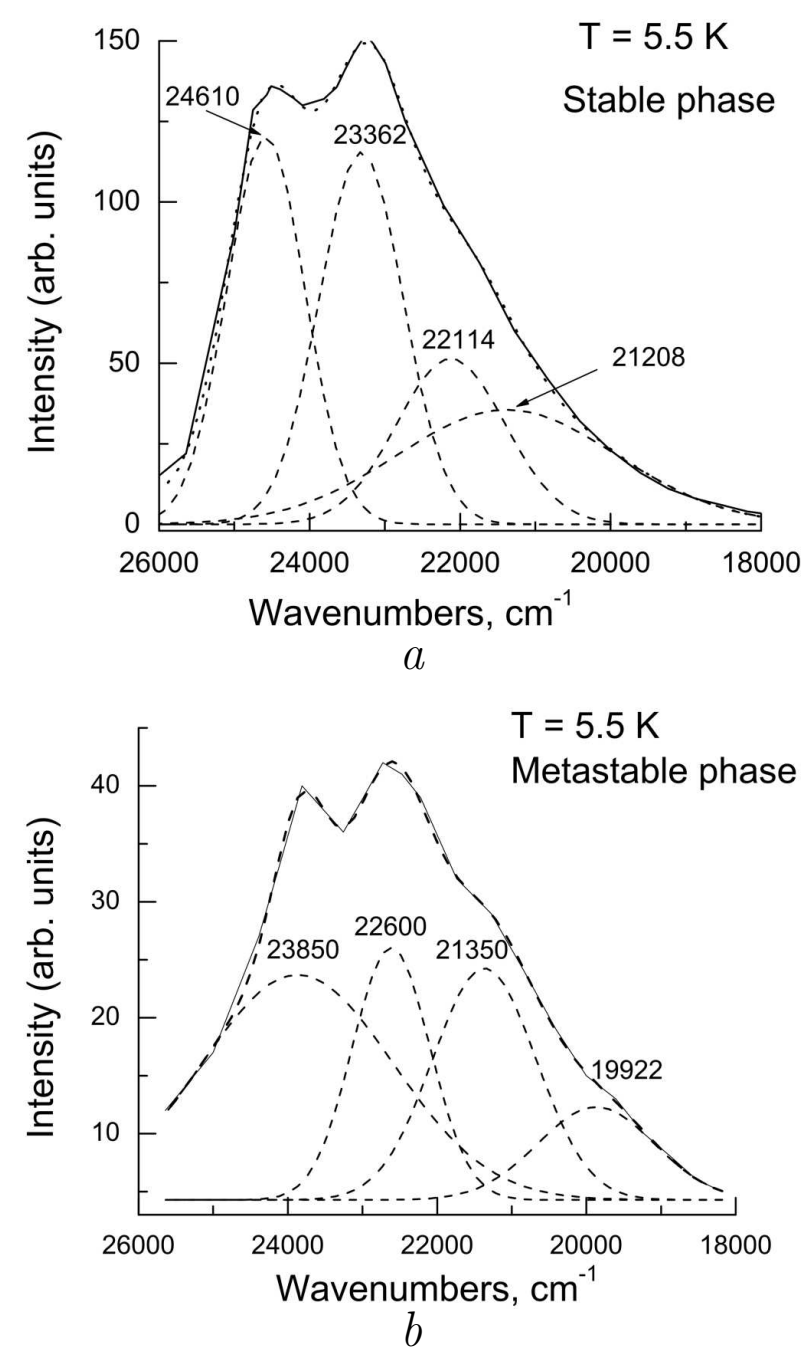

Fig. 3. Luminescence band of the stable (a) and metastable (b) phases of salol with respective Gaussian components at $5.5 \mathrm{~K}$. The top dotted curve shows the match of the total band (overlapping the experimental spectrum). The dashed low curves show the component bands

eral differences are found. The luminescence band of the metastable phase is down-shifted and broader relative to that of the stable phase.

Figures 3, $a, b$ show the Gaussian deconvolution of the luminescence bands at $5.5 \mathrm{~K}$ of the stable and metastable modifications, respectively. For the deconvolution of the luminescence bands, the program package Origin 5.0 was used, where the Fit Multi-peaks Gaussian menu command uses the Gaussian equation for fitting. The dotted top curves show the fitted spectrum overlapping the experimental spectrum. The dashed low curves show the component bands used to obtain the fitted spectrum. It is seen that both spectra consist of four well-resolved 

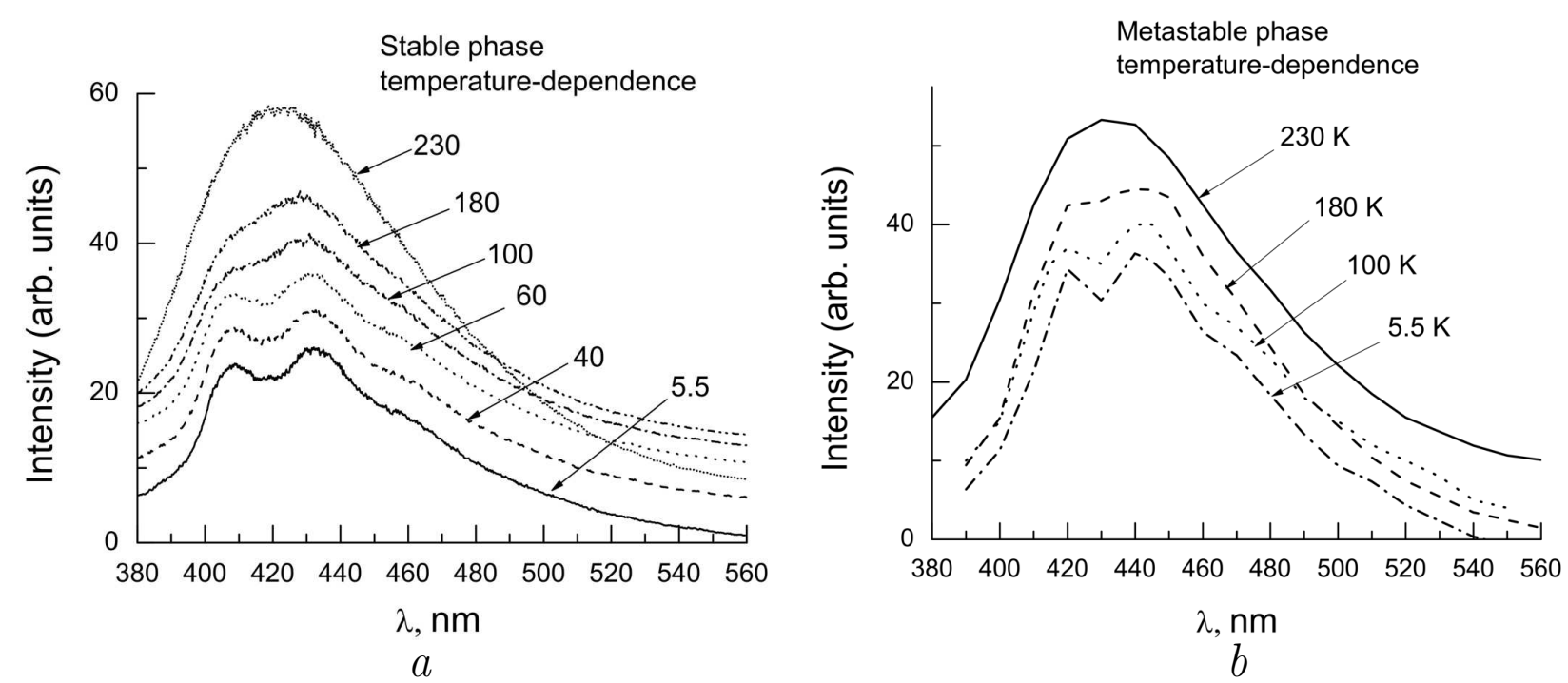

Fig. 4. Temperature-dependent luminescence spectra of the stable $(a)$ and metastable $(b)$ phases of salol. Spectra were measured in the temperature region from $5.5 \mathrm{~K}$ to $230 \mathrm{~K}$. The curves are shifted for clarity

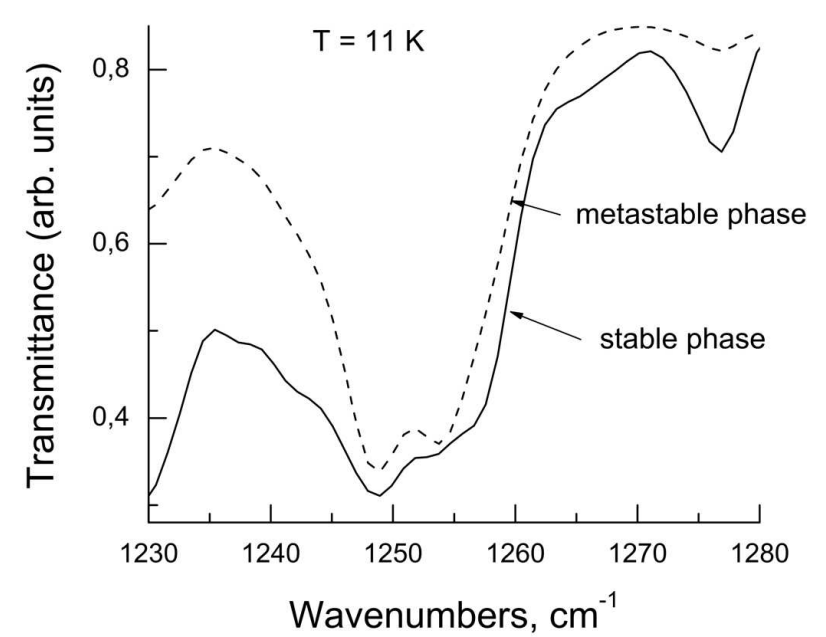

Fig. 5. IR transmittance spectra of the stable (solid curve) and metastable (dashed curve) phases of salol at $11 \mathrm{~K}$

bands. The average spacing between the first three bands is $1250 \mathrm{~cm}^{-1}$. The last band in both modifications is not the component of the progression. It is quite possible that an alternative emitter produce the fourth emission band. The emission of the metastable phase (Fig. 3,b) is shifted by $760 \mathrm{~cm}^{-1}$ relative to that of the stable phase (Fig. 3,a). The spectrum of the metastable phase has a full width at half-maximum (FWHM) amplitude of $3500 \mathrm{~cm}^{-1}$. The spectrum of the stable phase has $\mathrm{FWHM}=2500 \mathrm{~cm}^{-1}$.

The temperature-dependent luminescence spectra of the stable and metastable phases are shown in Figs. 4, $a$ and $4, b$, respectively. It is seen that the position of the luminescence band in the both phases practically do not change, as the temperature increases. At the same time, the vibronic structure on these bands is smearing, and both spectra show no sign of the vibronic structure at $230 \mathrm{~K}$.

We have used the IR spectroscopy method to identify the modes that give rise to the vibronic structure observed on the luminescence bands. Figure 5 shows the IR transmittance spectra of the stable and metastable modifications of salol recorded at $11 \mathrm{~K}$ in the 1230-1280 $\mathrm{cm}^{-1}$ spectral region. It is seen that there is the band at $1250 \mathrm{~cm}^{-1}$ in the IR spectra of both modifications of salol. According to quantum-chemical calculations of the vibrational frequencies for the normal modes of a salol molecule, the band at $1250 \mathrm{~cm}^{-1}$ is ascribed to the $\nu(\mathrm{C}-$ $\mathrm{OH})$ stretching vibration [16], which is involved into the intermolecular hydrogen-bonded interactions.

Figures 6, $a$ and $6, b$ show the temperature-dependent IR absorption spectra of the stable and metastable modifications of salol, respectively, recorded with decreasing temperature from $230 \mathrm{~K}$ to $11 \mathrm{~K}$ in the $1230-1280 \mathrm{~cm}^{-1}$ spectral region. It is seen that the behavior of the vibration band $\nu(\mathrm{C}-\mathrm{OH})$ in the both modifications is almost identical. The vibration frequency of this band practically does not depend on the temperature. However, the shape gradually changes with decreasing temperature. It splits into two components. The splitting appears more and more pronounced as the temperature decreases.

On the basis of the IR spectroscopy data, we can conclude that the progression interval $\left(1250 \mathrm{~cm}^{-1}\right)$ in the lu- 


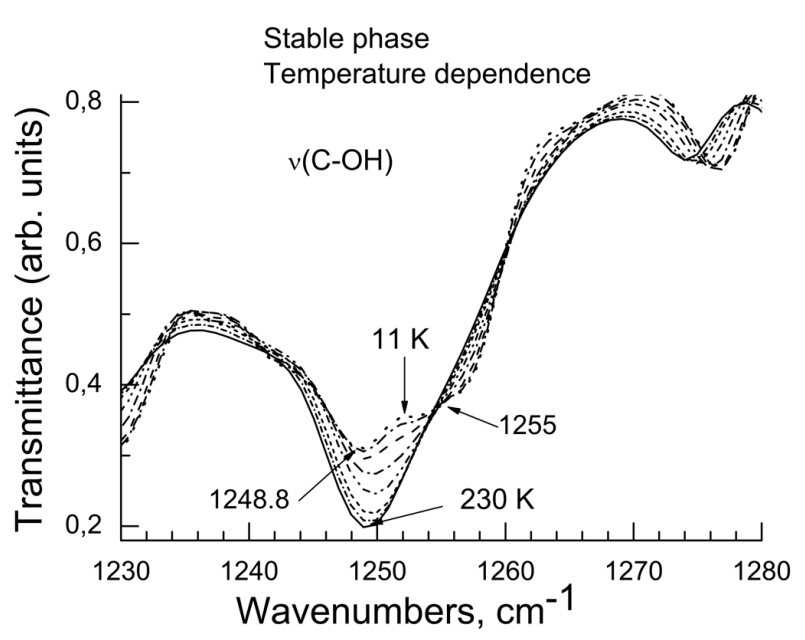

$a$

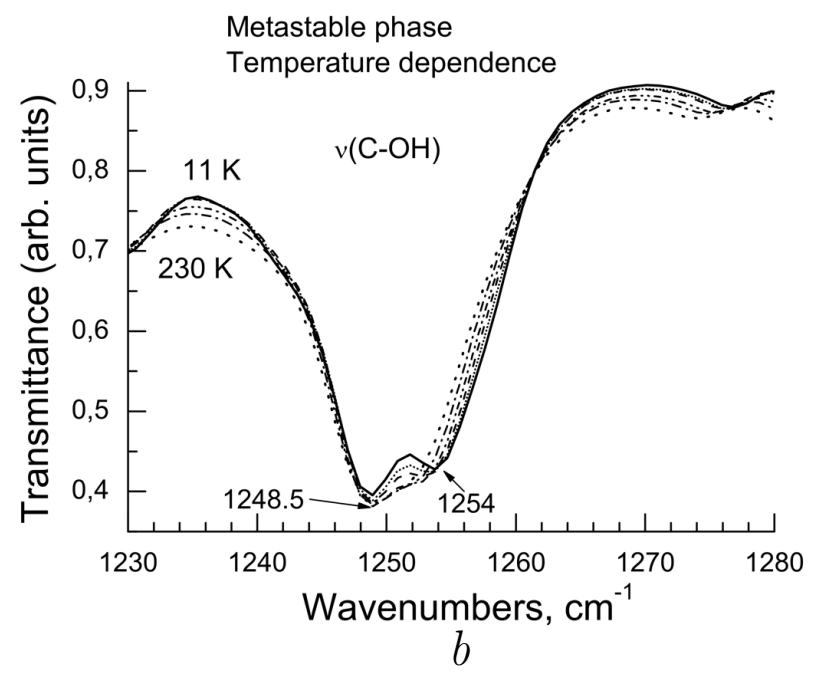

Fig. 6. Temperature-dependent IR spectra for the stable $(a)$ and metastable $(b)$ modifications of salol in the $1230-1280 \mathrm{~cm}^{-1}$ spectral region. The temperatures are (top to bottom): 11, 40,70,110, 150, 190, 210, and $230 \mathrm{~K}$

minescence spectra corresponds to the $\nu(\mathrm{C}-\mathrm{OH})$ stretching mode.

\section{Conclusion}

The luminescence spectra of different modifications of salol and their temperature dependences have been studied for the first time. It has been found that the luminescence spectra appear fairly similar, are asymmetric and broad, and have the vibronic structure. The Gaussian decomposition of the luminescence band shows the four components. The vibrational spacing between the first three components was found to be of about $1250 \mathrm{~cm}^{-1}$. The spectrum of the stable phase has a full width at halfmaximum amplitude of $2500 \mathrm{~cm}^{-1}$. The luminescence spectrum of the metastable phase has FWHM $=3500$ $\mathrm{cm}^{-1}$ and is down-shifted by $760 \mathrm{~cm}^{-1}$ relative to that of the stable phase. That fact gives a possibility to identify each modification of salol according to the position of the first emission band in the luminescence spectra. The progression interval in the luminescence spectra was combined with data from the IR transmittance spectra. It has been found that the vibration that gives rise to the vibronic structure on the luminescence band corresponds to the $(\mathrm{C}-\mathrm{OH})$ stretching vibration. Obviously, the presence of an $\mathrm{OH}$ group in the orto-position on the $\mathrm{OH}$-substituted ring (Fig. 1) asymmetrizes the molecule, by localizing the electronic excitation to the substituted ring.

1. M. Ramos, N.T. Correia, and H.P. Dioglo, Phys. Chem. Chem. Phys. 6, 793 (2006).
2. J. Baran, N.A. Davydova, and M. Drozd, J. Phys.: Cond. Matt. 22, 155108 (2010).

3. W.M. Du, G. Li, H.Z. Cummins, M. Fuchs, J. Toulouse, and L.A. Knauss, Phys. Rev. E 49, 2192 (1994).

4. C. Dreyfus, M.J. Lebon, H.Z. Cummins, J. Toulouse, B. Bonello, and R.M. Pick, Phys. Rev. Lett. 69, 3666 (1992).

5. G. Pratesi, A. Bellosi, and F. Barocchi, Eur. Phys. J. B 18, 283 (2000).

6. G. Li, W.M. Du, A. Sakai, and H.Z. Cummins, Phys. Rev. A 46, 3343 (1992).

7. H.Z. Cummins, W.M. Du, M. Fuchs, W. Gotze, S. Hildebrand, A. Latz, G. Li, and N.J. Tao, Phys. Rev. E 47, 4223 (1993).

8. A.G. Kalampounias, S.A. Kirillov, W. Steffan, and S.A. Yannopoulos, J. Mol. Str. 651-653, 475 (2003).

9. G. Hinze, D.D. Brace, S.D. Gotke, and M.D. Fayer, Phys. Rev. Lett. 84, 2437 (2000).

10. H. Cang, V.N. Novikov, and M.D. Fayer, J. Chem Phys. 118, 2800 (2000).

11. H. Cang, V.N. Novikov, and M.D. Fayer, Phys. Rev. Lett. 90, 197401 (2003).

12. R. Casalini, M. Paluch, and C.M. Roland, J. Phys. Chem. A 107, 2369 (2003).

13. F. Stickel, E.W. Fischer, and R. Richert, J. Chem. Phys. 102, 6251 (1995).

14. J.H. Bilgram, U. During, M. Wachter, and P. Seiler, J. Cryst. Growth 57, 1 (1982).

15. R.B. Hammond, M.J. Jones, K.J. Roberts, H. Kutzke, and H. Klapper, Zeit. für Krist. 217, 484 (2004).

16. J. Hanuza, W. Sasiadek, J. Michalski, J. Lorenc, M. Maczka, A.A. Kaminski, A.V. Butashin, H. Klapper, 
J. Hulliger, and A.F.A. Mohamed, Vib. Spectrosc. 34, 253 (2004).

Received 22.09.11

РІЗНІ ПОЛІМОРФНІ МОДИФІКАЦІЇ ФЕНІЛСАЛІЦИЛАТУ

Н.О. Давидова, В.І. Мельник, В.В. Несправа, В.Я. Резніченко $\mathrm{P}$ е з ю м е

Вперше отримано спектри люмінесценції двох поліморфних форм фенілсаліцилату (салолу). В обох спектрах виявлено ві- бронну структуру. Середня відстань між вібронними компонентами становить $1250 \mathrm{~cm}^{-1}$. На основі даних інфрачервоної спектроскопії встановлено, що інтервал між компонентами $\left(1250 \mathrm{~cm}^{-1}\right)$ у спектрі люмінесценції відповідає валентному коливанню $\nu(\mathrm{C}-\mathrm{OH})$, яке бере участь в утворенні міжмолекулярного водневого зв'язку. Спектр люмінесценції метастабільної фази зміщений у довгохвильовий бік на $760 \mathrm{~cm}^{-1}$, і він суттєво ширший за спектр стабільної фази. Наявність ОН групи в ортоположенні на одному з кілець викликає асиметрію молекули та локалізацію електронного збудження на кільці з ОН заміщенням. 